Ecclesia. Studia z Dziejów Wielkopolski t. 13 (2018)

doi: 10.14746/e.2018.13.2

\author{
MARCIN PUZIAK \\ Wyższe Seminarium Duchowne Diecezji Bydgoskiej \\ Bydgoszcz
}

\title{
O wielkopolskich kazaniach ojca Szymona od św. Antoniego, karmelity. Przyczynek do historii kaznodziejstwa w Wielkopolsce czasów saskich
}

Dzieje karmelitów w Polsce, zwanych dawniej trzewiczkowymi, są w dużej części jeszcze mało znane. Wprawdzie poza ogólnym zarysem ich historii istnieje już pewna liczba opracowań ukazujących niektóre klasztory, poszczególne postacie czy działalność w jakimś wybranym okresie i w określonej dziedzinie $^{1}$, jednak do całościowego, kompletnego chronologicznie i aspektowo ujęcia jest wciąż jeszcze daleko.

Współczesna kultura mediów elektronicznych, która pozwala zabezpieczać dziedzictwo czasów przeszłych i jednocześnie łatwiej udostępniać je badaczom, pomaga odkrywać niektóre ślady działalności karmelitów i to czasami w miejscach, gdzie nawet nikt nie spodziewał się czegoś takiego znaleźć. Takim odnalezionym śladem działalności karmelitańskiej jest XVIII-wieczna książka pt. Dyaryusz odświętny roku kaznodziejskiego autorstwa o. Szymo-

\footnotetext{
${ }^{1}$ Zob. np.: I. Chodynicki, Wiadomość historyczna o fundacjach klasztorów zakonu karmelitańskiego niegdyś w Polsce i na Litwie, Lwów 1846; T.M. Trajdos, U zarania karmelitów w Polsce, Warszawa 1993; B. Panek, Karmelici, [w:] Encyklopedia katolicka (dalej: EK), t. 8, Lublin 2000, kol. 804-808, tam też bibliografia podstawowa. Poszczególnych klasztorów dotyczą następujące wybrane prace: dla Bydgoszczy - Karmelitańskie dziedzictwo Bydgoszczy, red. M. Puziak, Bydgoszcz 2017; dla Kcyni - A. Szudrowicz, Karmelici w Kcyni (1612-1835). Rola zakonu w życiu miasta i okolicy, Bydgoszcz 2001; dla Kłodawy - B. Grzanka, Dziedzictwo Karmelu. 250 lat kościoła Wniebowzięcia Najświętszej Maryi Panny w Kłodawie, Kłodawa 2016; dla Obór - M. Krajewski, Oborzańskie Sanktuarium Matki Bożej Bolesnej Pani i Królowej Ziemi Dobrzyńskiej, Kraków-Obory-Brodnica 2016; dla Poznania (Rezydencja pw. Krwi Chrystusa) - Kroniczka rezydencji Karmelitów Trzewiczkowych w Poznaniu, oprac. J. Wiesiołowski, Poznań 2005; dla Trutowa - M. Krajewski, Pod szata Karmelu. Kościót i klasztor Karmelitów w Trutowie, Trutowo-Brodnica 2016; 300 lat karmelitów w Trutowie, red. J. Dębiński, Trutowo 2017.
} 
na od św. Antoniego ${ }^{2}$. Do dziś, choć odnotowana w Bibliografii Estreichera, nie przyciągnęła uwagi badaczy, chyba z powodu opinii o jej przeciętności ${ }^{3}$, a może także $\mathrm{z}$ racji trudności $\mathrm{w}$ dotarciu do zachowanych egzemplarzy. Obecnie zdigitalizowana, jest udostępniona przez Sandomierską Bibliotekę Cyfrową ${ }^{4}$ Książka jest zbiorem kazań. Wśród nich znalazły się również kazania wygłoszone w Poznaniu i kilku innych miejscach Wielkopolski. Ta okoliczność przyciąga do nich naszą uwagę.

\section{Szymon od św. Antoniego}

O należącym do prowincji wielkopolskiej Najświętszego Sakramentu karmelitów strictioris observantiae 5 ojcu Szymonie od św. Antoniego mamy mało wiadomości ${ }^{6}$. Nie wiemy, jakie było jego imię chrzestne i nazwisko rodowe. Urodził się w roku 1694. W 1714 roku wstąpił do zakonu karmelitów, a po rocznym nowicjacie złożył profesję zakonną (1715). Formację zakonną i kapłańską otrzymał zasadniczo w Bydgoszczy i Warszawie. Po święceniach (przed 1721 rokiem) został wyznaczony najpierw do konwentu bydgoskiego jako lektor filozofii, a później do Warszawy. Najprawdopodobniej jeszcze w 1724 roku trafił do poznańskiego konwentu pw. Bożego Ciała. We wspólnocie poznańskiej zdobył sobie pewne uznanie, o czym świadczy fakt, że w 1727

${ }^{2}$ Dyaryusz odświętny roku kaznodzieyskiego należyta pilnościa wyrachowany chrześcijańskim pobożnościom z Ambony zalecony albo Kazania roczne na uroczystości świętych Pańskich przez W.X. Szymona od S. Antoniego [...] miane, po śmierci jego zebrane i do druku podane, Gdańsk 1751 (dalej: Dyaryusz). Por. K. Estreicher, Bibliografia polska, t. XXX, s. 340.

3 ,Z połowy 18. wieku istnieje zbiór różnych kazań mianych przez przeora karmelitów gdańskich Szymona od św. Antoniego. Wszystkie te kazania nie różnią się od innych przeciętnych w tychże czasach wygłaszanych”. A. Mańkowski, Dzieje drukarstwa i piśmiennictwa polskiego w Prusiech Zachodnich ze szczegółowa bibliografia druków polskich zachodniopruskich, „Roczniki Towarzystwa Naukowego w Toruniu" t. 18, 1911, s. 105.

${ }^{4}$ Por. http://bc.bdsandomierz.pl. Autor niniejszego artykułu korzystał z egzemplarzy przechowywanych w bibliotece klasztoru w Oborach, a w tym miejscu dziękuje przeorowi o. Włodzimierzowi Durbasowi O.Carm. oraz byłemu definitorowi o. Wiesławowi Strzeleckiemu O.Carm. za udostępnienie tej księgi do lektury i badań.

${ }^{5} \mathrm{~W}$ łonie zakonu karmelitów, zwanych trzewiczkowymi (calceati) albo dawnej obserwancji (antiquae observantiae), powstał ruch reformatorski zwany reformą turoneńską. Klasztory, które przyjęły ten sposób życia, nazywane były domami ściślejszej obserwancji (strictioris observantiae). W Polsce jeszcze w XVII wieku reformę przyjęło kilkanaście klasztorów. Od 1728 roku tworzyły one odrębną prowincję wielkopolską ściślejszej obserwancji pw. Najświętszego Sakramentu. Por. B. Panek, W. Kolak, Karmelici, [w:] EK, t. 8, kol. 806, 811.

${ }^{6}$ Por. G. Kloskowski, Karmelici trzewiczkowi prowincji wielkopolskiej w XVII-XIX wieku, „Archiwa, Biblioteki i Muzea Kościelne” 98 (2012), s. 242 (przypis 995). Obszerniejsza biografia o. Szymona, zob.: M. Puziak, Szymon od św. Antoniego - karmelitański kaznodzieja w Bydgoszczy i okolicy w czasach saskich, „Materiały do Dziejów Kultury i Sztuki Bydgoszczy i Regionu” 19 (2018), s. 23-42. Tutaj ograniczamy się do niezbędnych wiadomości. 
roku współbracia wybrali go socjuszem przeora na kapitułę prowincjalną. $\mathrm{Na}$ tejże kapitule oddano na niego jeden głos w wyborach na podprzeora poznańskiego. Do Poznania wrócił jako kaznodzieja. Trzy lata później, w kapitule w 1730 roku, uczestniczył znowu jako socjusz poznański. Tym razem kapituła wybrała go podprzeorem w konwencie bydgoskim, co oznaczało dla niego opuszczenie Poznania i przeniesienie się do Bydgoszczy. Był zatem w klasztorze w Bydgoszczy przez jedną kadencję zastępcą przeora, a następnie pełnił różne inne funkcje. W klasztorze bydgoskim pozostawał do 1739 roku, kiedy to obradująca wówczas kapituła prowincjalna wybrała go przeorem w Gdańsku. Pełniąc ten urząd, zmarł w 1740 roku. Według nekrologu żył 45 lat, w tym 25 lat od złożenia profesji zakonnej ${ }^{7}$.

\section{Dyaryusz odświętny roku kaznodzieyskiego}

Tom kazań o. Szymona od św. Antoniego, Dyaryusz odświętny roku kaznodziejskiego [...] został opublikowany po jego śmierci. Nie wiemy, czy sam o. Szymon nosił się z zamiarem ich wydania, czy też zachowane w rękopisach kazania w oczach jego współbraci były na tyle godne uwagi, że zdecydowano się wydać je drukiem. Trudno przypuścić, by były jakieś inne powody dokonania publikacji. W proces wydawniczy - na pewnym jego etapie - zaangażowani byli zakonnicy z tytułu pełnionych przez nich urzędów i funkcji. Decyzja o publikacji należała do prowincjała, który z kolei opierał się na opinii zakonników ustanowionych cenzorami. $Z$ zamieszczonych w książce not dowiadujemy się, że prowincjałem tym był o. Jan od św. Władysława, sam piszący i dbający o publikacje zakonne ${ }^{8}$; ponadto widnieją imiona dwóch innych zakonników sprawujących w tym czasie odpowiedzialne funkcje w prowincji zakonnej: o. Leonard od św. Jana, przeor gdański oraz o. Alan od św. Gerarda, definitor prowincjalny.

Rok wydania nie jest tak oczywisty, jak by się mogło wydawać. Na stronie tytułowej widnieje rok 1751, z kolei Estreicher podaje rok katalogu księgarskiego - 1754. Noty opublikowane na pierwszych stronach (aprobaty cenzorów i opinie teologiczne oraz aprobata generała zakonu z Rzymu) rzeczywiście każą urealnić druk przynajmniej na rok 1753. Na miejsce druku wybrano

\footnotetext{
${ }^{7}$ Por. Archiwum Karmelitów w Krakowie na Piasku (dalej: AKK), Decretale provinciae strictioris observantiae, sygn. AKKr 168/397, passim. Zob. W. Kolak, Katalog Archiwum OO. Karmelitów w Krakowie na Piasku 1398-1945 (1988), Kraków 1997, s. 100.

${ }^{8}$ Por. M. Puziak, Uwagi o prowincjałach karmelitańskiej Wielkopolskiej Prowincji Najświętszego Sakramentu w XVIII w., „Studia Bydgoskie” 11 (2017), s. 177-178; W. Murawiec, Jan od św. Władysława, [w:] Stownik polskich teologów katolickich (dalej: SPTK), t. 2, Warszawa 1982, s. 129-130.
} 
gdańską drukarnię Tomasza Jana Szreibera, „szlachetnego Magistratu y sławnego Gymnasium" drukarza9.

Do dziś zachowało się w bibliotekach polskich przynajmniej kilka egzemplarzy Dyaryusza odświętnego. Z pewnością znajdują się w Sandomierzu, Lublinie ${ }^{10}$ i Oborach - tu dwa egzemplarze. Tych miejsc nie spotykamy u Estreichera, który w swoich czasach odnotował obecność tej pozycji w bibliotece pobernardyńskiej w Świeciu oraz w Bibliotece Uniwersyteckiej w Warszawie ${ }^{11}$. Tak mała liczba znanych egzemplarzy książki, która wydana została w połowie XVIII wieku, może świadczyć o niewielkim nakładzie lub o słabym zainteresowaniu dziełem, czy też wręcz odwrotnie: zainteresowanie nim mogło być tak duże, że doprowadziło do „zaczytania” wielu egzemplarzy i tym sposobem nie dotrwały do dzisiaj. Nie można wreszcie wykluczyć, że egzemplarzy obecnie istniejących jest więcej i znajdują się w zbiorach starodruków, które nie zostały skatalogowane bądź których katalogi nie są ogólnie dostępne.

\section{Kaznodzieje karmelitańscy w Poznaniu w 1. połowie XVIII wieku}

W prowincji wielkopolskiej karmelitów, do której należał o. Szymon, ustanawiano kaznodziejami - concionatores - zakonników lepiej przygotowanych przez studia i dydaktykę. Często byli to lektorzy filozofii i teologii, a zdarzali się i lektorzy retoryki. Typowa droga takiego zakonnika przebiegała według schematu: po święceniach zostawał najpierw lektorem filozofii (czasem przedtem retoryki), potem teologii, po latach wykładania otrzymywał tytuł jubilatus, a po przynajmniej dziesięciu latach tytuł emeritus. Tytuł doktora przysługiwał zakonnikom, którzy odbyli odpowiednią publiczną dysputę albo w którymś ze studiów generalnych (studium generale), albo przed generałem zakonu - on zresztą też zatwierdzał ostatecznie ten tytuł równoznaczny z tytułem uniwersyteckim. Urząd kaznodziei był pełniony często równolegle z wykładaniem

${ }^{9}$ Por. Z. Nowak, Schreiber Thomas Johannes (1699-1778), [w:] Polski stownik biograficzny, t. 35, Warszawa-Kraków 1994, s. 636-637; M. Pelczarowa, Z dziejów oficyn drukarskich w Gdańsku (w. XVI-XVIII), „Rocznik Gdański” 14 (1955), s. 145-165; A. Jędrzejowska, M. Pelczarowa, Polskie piśmiennictwo $w$ gdańskich oficynach drukarskich (XVI-XVIII w.), [w:] Szkice z dziejów Pomorza, t. 2: Pomorze nowożytne, red. G. Labuda, S. Hoszowski, Warszawa 1959, s. 118-133; M. Pelczarowa, Z dziejów oficyn drukarskich w Gdańsku (XVI-XVII w.), Gdańsk 1995. Wiadomo, że ten sam drukarz przygotowywał dla karmelitów gdańskich także przynajmniej jeden z tomów (IV) Scrutinium Iuris Eliasza od św. Franciszka (Idlińskiego). Por. K. Estreicher, Bibliografia polska, t. XVIII, s. 519-520.

${ }^{10}$ Egz. z biblioteki mariańskiej z Puszczy Korabiewskiej, por. W. Karpiuk, Biblioteka Marianów w Puszczy Korabiewskiej, „Archiwa, Biblioteki i Muzea Kościelne” t. 69 (1998), s. 284.

${ }^{11}$ K. Estreicher, Bibliografia polska, t. XXX, s. 340. 
filozofii lub teologii, ale nierzadko było tak, że zakonnik bywał przeznaczany tylko do tej posługi - jak się zdaje był to również przypadek o. Szymona. Zawsze jednak uznawano posługę kaznodziei za tak istotną, że nie pozostawiano wolności w sprawie przydziału tego obowiązku przeorowi danego klasztoru, ale podejmowała taką decyzję kapituła lub definitorium prowincjalne ${ }^{12}$.

Znaczniejsze konwenty prowincji miały czasami więcej niż jednego kaznodzieję. Drugi zakonnik wyznaczony do głoszenia kazań był nazywany albo drugim kaznodzieją, albo kaznodzieją pomocnikiem (coadiutor); najczęściej pełnili swoją posługę na zmianę. Czasami określano precyzyjniej podział obowiązków według różnych kryteriów, np. językowego (concionator Polonorum lub Germanorum), pory dnia (matutinus albo pomeridianus) lub liturgicznej rangi dni głoszenia kazań (festivalis, dominicalis lub ferialis).

W epoce saskiej, aż po lata 60. XVIII wieku, czyli mniej więcej w okresie życia zakonnego o. Szymona, który obejmował lata 1715-1740, w konwencie poznańskim pw. Bożego Ciała byli ustanowieni przez kolejne kapituły następujący kaznodzieje ${ }^{13}$ :

\begin{tabular}{|c|c|}
\hline Kapituła & Kaznodzieje \\
\hline \multirow[t]{3}{*}{1703} & Bazyli od Trójcy Świętej \\
\hline & Justynian od św. Macieja - pomocnik \\
\hline & Eliasz od św. Franciszka - pomocnik \\
\hline \multirow[t]{2}{*}{1706} & Gerwazy od św. Marcelina \\
\hline & Justynian od św. Macieja \\
\hline 1709 & Leon od św. Teresy \\
\hline 1712 & $\begin{array}{l}\text { Arnold od Trójcy Świętej - kaznodzieja nadzwyczajny } \\
\text { Józef od św. N.O. Eliasza - kaznodzieja zwyczajny }\end{array}$ \\
\hline 1715 & Rajmund od Narodzenia NMP \\
\hline 1718 & Bartłomiej od św. Adriana \\
\hline 1721 & Bartłomiej od św. Adriana \\
\hline \multirow[t]{2}{*}{1724} & Julian od Objawienia Pańskiego \\
\hline & Stefan od Oczyszczenia NMP \\
\hline \multirow[t]{2}{*}{1727} & Szymon od św. Antoniego \\
\hline & Wincenty od św. Stanisława - pomocnik \\
\hline
\end{tabular}

12 Podobnie zagadnienie to przedstawiało się w innych zakonach mendykanckich. Zob. J. Flaga, Działalność duszpasterska zakonów w drugiej połowie XVIII w. (1767-1772), Lublin 1986; tenże, Działalność duszpasterska zakonów franciszkańskich na ziemiach Rzeczypospolitej w trzeciej ćwierci XVIII wieku (w świetle ankiety zakonnej nuncjusza Giuseppe Garampiego z lat 1773-1774), [w:] Zakony franciszkańskie w Polsce, red. J. Kłoczowski, t. 2: Franciszkanie w Polsce XVI-XVIII wieku, cz. 1, Niepokalanów 1998, s. 338-384.

${ }^{13}$ Zestawienie sporządzone na podstawie: AKK, Decretale provinciae strictioris observantiae, sygn. AKKr 168/397, passim. 
1730 Adrian od św. Jana Ewangelisty

Chryzostom od św. Wawrzyńca - pomocnik

1733 Gerard od św. Jakuba

1736 Gabriel od św. Antoniego

1739 Norbert od św. Walentego

1742 Narcyz od św. Zachariasza

1745 Ferdynand od św. Kasjana

1748 Teodor od św. Cecylii

1751 Kanty (Kancjusz) od św. Juliana

1754 Sebastian od Zaślubin NMP

1757 Brunon od św. Franciszka

Benedykt od św. Ignacego - pomocnik

Norbert od św. Walentego - jubilatus, podprzeor

1760 Reginald od św. Alberta

Alfons od św. Mateusza - pomocnik

Walenty od św. Agnieszki - jubilatus, podprzeor

1763 Piotr od św. Teresy - kaznodzieja domowy i promotor bractwa szkaplerznego

Bonawentura od św. Jakuba - świąteczny

Do wykazu tego należałoby dodać zmiany, które w obsadzie konwentu, a co za tym idzie także na urzędzie kaznodziei, były dokonywane decyzją definitorium prowincjalnego albo samego prowincjała lub generała, wreszcie także w wyniku zgonu zakonników; pomijamy je jednak tutaj, bo nie one stanowią centrum naszego zainteresowania.

W powyższym spisie, oprócz o. Szymona, przyciągają uwagę dwie inne osoby: Eliasz od św. Franciszka i Kanty (Kancjusz) od św. Juliana. Obaj byli zakonnikami dobrze wykształconymi, wybijającymi się pod względem intelektualnym oraz mogącymi poszczycić się publikacjami. Odnosi się to zwłaszcza do o. Kantego od św. Juliana, profesora retoryki i wziętego kaznodziei ${ }^{14}$.

\section{Kaznodziejstwo o. Szymona}

W kazaniach o. Szymona uderza skoncentrowanie na moralności chrześcijańskiej. Konceptualizm charakterystyczny dla konstrukcji tych kazań czasami

${ }^{14}$ Por. odpowiednio: dla Eliasza od św. Franciszka: K. Estreicher, Bibliografia polska, t. XVIII, s. 519-520; W. Murawiec, Idliński Eliasz od św. Franciszka, [w:] SPTK, t. 2, Warszawa 1982, s. 86; M. Puziak, Uwagi o prowincjałach, s. 174-175, a dla Kantego od św. Juliana: K. Estreicher, Bibliografia polska, t. XIV, s. 47-48. 
jest bardzo wyrafinowany, a czasami uderzająco prosty, zawsze doprawiony cytatami biblijnymi, odniesieniami do mitologii oraz do historii polskiej lub innych narodów. W centrum uwagi pozostaje jednak osoba świętego, któremu poświęcone jest kazanie. Kaznodzieja czyni wysiłki, by swoich słuchaczy pobudzić może nie tyle do naśladowania danego świętego, ile do przemyślenia i poprawy w zakresie jakiegoś konkretnego moralnego lub religijnego aspektu postępowania. Trzeba przyznać, że o. Szymon umiał patrzeć na ludzi sobie współczesnych przenikliwie i krytycznie, a choć nie zawsze krytykuje ich wprost, zawsze jednak zaprasza do konkretnych dobrych i właściwych postaw i czynów.

Nie wiadomo, czy teksty podane do druku są w pełni zgodne z kazaniami wygłoszonymi, czy też może zostały w stosunku do nich nieco zmienione. Niemniej wydrukowany tekst robi wrażenie bardzo oględnego, nie ma w nim sformułowań ostrych, nie ma krytyki zachowań środowiska, które reprezentowali słuchacze. Nie ma uwag o charakterze napiętnowania. Jeśli jakaś uwaga odnosi się bezpośrednio do słuchaczy lub środowiska, do którego należą, to zdarza się to bardzo rzadko. Oczywiście nie można posądzać o. Szymona, że nie był świadomy braków, wad czy win swoich słuchaczy jako pewnej społeczności, jednak, jak zostało powiedziane, mocnej krytyki i napiętnowania nie stosuje. Brak odniesienia do konkretnych realiów powoduje, że kazania nie dostarczają zbyt wielu informacji o mikroświecie Poznania czy innych miejscowości wielkopolskich, gdzie o. Szymon głosił kazania. Z drugiej jednak strony opublikowane teksty kazań wprost, albo częściej pośrednio, pozwalają poznać mentalność, obyczaje i kulturę tamtej epoki.

Zamieszczone przy kazaniach informacje o czasie i miejscu ich wygłoszenia są ciekawym przyczynkiem do rekonstrukcji posługi kaznodziejskiej o. Szymona w Poznaniu i niektórych innych miejscowościach wielkopolskich, a garść innych uwag daje, choć w swej istocie drobne, ale cenne lub przynajmniej interesujące, informacje także o miejscach, przedmiotach i wydarzeniach dziś nam słabo znanych albo nieznanych wcale.

\section{Poznańskie kazania o. Szymona}

Część kazań wydrukowanych w Dyaryuszu nie jest datowana. W wielu jednak przypadkach data roczna została podana. Do tego dochodzą informacje o miejscu i okazji wygłoszenia kazania. Okazją był najczęściej jakiś obchód liturgicznej uroczystości czy święta. Wykaz datowanych kazań w kościołach poznańskich w układzie chronologicznym i z podaniem stron w Dyaryuszu przedstawia się następująco: 
1724 kościół reformatów - kazanie na dzień św. Franciszka (s. 333$-338)$,

1725 kościół jezuitów - kazanie na Nowy Rok (s. 1-6),

1727 kościół jezuitów - kazanie II na Nowy Rok (s. 7-12),

1727 kościół dominikanów - kazanie II na dzień św. Jacka (s. 257-263),

1727 kościół karmelitów (Bożego Ciała) - kazanie na dzień Znalezienia Najśw. Hostii (Niedziela XIII po Świątkach) oraz święto Opatrzności Bożej (s. 277-281),

1727 kościół franciszkanów - kazanie II na dzień św. Franciszka (s. 338-344),

1727 kościół karmelitów (Bożego Ciała) - kazanie na dzień św. Szymona i Judy Apostołów, patronów bractwa Opatrzności Bożej (s. 365-370),

1728 kościół karmelitów bosych - kazanie na dzień św. Józefa (s. 58$-62)$,

1728 kościół reformatów - kazanie przy introdukcji nowo kanonizowanych świętych z zakonu św. Franciszka (s. 78-84),

1728 kościół karmelitów (Bożego Ciała) - kazanie II na dzień Znalezienia Trzech Hostii (Niedziela XV po Świątkach) oraz na uroczystość Bożej Opatrzności (s. 282-288),

1728 kościół karmelitów (Bożego Ciała) - kazanie na dzień św. Michała Archanioła; wotywa przed Trzema Hostiami, przy błogosławieństwie nowych urzędników miejskich (s. 321-326),

1729 kościół karmelitów bosych - na dzień św. Jozefa (s. 62-67),

1729 kościół dominikanów - kazanie na dzień Nawiedzenia Najśw. Panny Maryi, przy prymicjach (s. 163-168),

1729 kościół karmelitów (Bożego Ciała) - kazanie na dzień Bożego Ciała (s. 137-142),

1729 kościół karmelitów (Bożego Ciała) - kazanie II na dzień św. Szymona i Judy (s. 370-374),

1730 kościół karmelitów (Bożego Ciała) - kazanie podczas Oktawy Bożego Ciała (s. 142-147),

1730 kościół klarysek (bernardynek) - kazanie na dzień św. Klary (s. 232-246),

1731 kościół karmelitów - przy zaczęciu nowenny przed uroczystością Narodzenia Najświętszej Panny (s. 288-295) ${ }^{15}$,

1733 kościół jezuitów - kazanie na dzień św. Ignacego (s. 206-215).

${ }^{15}$ W Dyaryuszu (s. 295-301) znajduje się także kazanie „Przy konkluzyi tegoż nabożeństwa”, ale nie jest ono w żaden sposób opisane i w treści też nie ma żadnego odniesienia potwierdzającego jego wygłoszenie w Poznaniu, dlatego je opuszczamy. 
Prawdopodobnie kazań wygłoszonych w samym Poznaniu, a wydrukowanych w Dyaryuszu, jest więcej, nie wszystkie jednak zostały opatrzone datą i miejscem wygłoszenia. Co do kilku możemy podejrzewać, że wygłoszone były w Poznaniu, np. kazanie, w którym o. Szymon wspomina zupełnie dziś zapomnianego patrona Poznania, św. Andrzeja Korsyna (Corsini) ${ }^{16}$.

Prawie wszystkie z wymienionych kazań pochodzą z lat 1727-1730, a więc z poświadczonego okresu pełnienia przez o. Szymona urzędu kaznodziei w Poznaniu. Dwa kazania pochodzą z lat 1724 i 1725, a więc poprzedzają ten okres, ale już wówczas o. Szymon przebywał w Poznaniu. Musiała zatem pojawić się jakaś nadzwyczajna sytuacja, skoro nie będąc kaznodzieją $\mathrm{z}$ urzędu, kazania wygłosił i do tego zostały one wydrukowane w omawianym tomie. Może zaszła konieczność zastąpienia kaznodziei w czasie jego nieobecności lub choroby. Natomiast po roku 1730, jak już wyżej wspomniano, o. Szymon przebywał w klasztorze w Bydgoszczy, stąd jego obecność w Poznaniu miała charakter nadzwyczajny i zapewne wiązała się ze specjalnym zaproszeniem, a ze strony przełożonych $-\mathrm{z}$ osobnym pozwoleniem ${ }^{17}$. Te dwa kazania opatrzone datami 1731 i 1733 można potraktować jeszcze inaczej, mianowicie podać w wątpliwość ich wygłoszenie rzeczywiście w Poznaniu. Na obecnym etapie badań i wiedzy nie można jednak niczego pewnego w tej kwestii powiedzieć.

Spośród dziewiętnastu kazań, których miejsce wygłoszenia podano, aż osiem o. Szymon wygłosił we własnym kościele klasztoru, do którego należał, a więc w kościele pw. Bożego Ciała, co jest zupełnie zrozumiałe, gdyż właśnie w tym kościele wykonywał swój urząd kaznodziei. Wszystkie inne, co do których Dyaryusz podaje miejsce, zostały wygłoszone w kościołach innych zakonów mających swoje siedziby w Poznaniu: trzy u jezuitów, po dwa u reformatów, karmelitów bosych i dominikanów, a po jednym u franciszkanów i klarysek (bernardynek). Nie ma zatem żadnego, które byłoby wygłoszone w świątyni parafialnej. Istnieje pokusa, aby widzieć w tym wyraz solidarności zakonnej albo przejaw niechęci między zakonami i duchowieństwem diecezjalnym. Nie dysponujemy jednak żadnym dowodem, by ta ostatnia sprawa była powodem nieobecności w Dyaryuszu kazań wygłoszonych w którymś z poznańskich kościołów niezakonnych.

${ }^{16}$ Dyaryusz, s. 35-41.

${ }^{17}$ Z okresu po 1730 roku opisano: pięć kazań w Bydgoszczy, po dwa w Koronowie i Byszewie, jedno w Kcyni (zob. M. Puziak, Szymon od św. Antoniego, 23-42). Są też dwa kazania z Gdańska, oba z roku 1725. 


\section{Uwagi do poszczególnych kazań}

Analizę teologiczną, hagiograficzną, homiletyczną i językową pozostawiamy omówieniu $\mathrm{w}$ innym miejscu. Tutaj interesują nas zawarte w kazaniach o. Szymona wiadomości natury historycznej, dotyczące bezpośrednich okoliczności ich wygłoszenia: czasu, miejsca lub obecnych osób, czyli to, co czyni te teksty w jakiś sposób dokumentem zewnętrznych okoliczności ich wygłoszenia. Jak już wspomniano, z lektury kazań o. Szymona wynika, że nie był on skłonny czynić bezpośrednich odniesień do bieżących wydarzeń czy spraw dotyczących środowiska swoich słuchaczy, jeśli pominie się uwagi o charakterze moralizatorskim, zawsze bardzo ogólnym. Nie znaczy to, że się one nie pojawiają.

Z drugiej strony warto zaznaczyć, że karmelitański kaznodzieja choć jest względnie dobrze zaznajomiony $z$ historią i wiele razy sięga do wydarzeń historycznych mniejszej lub większej wagi, to jednak zawsze wykorzystuje je jedynie jako kaznodziejskie exemplum, co sprawia, że pozostaną tu poza zasięgiem naszego zainteresowania, jako takie bowiem znajdą się w tekście poświęconym analizie teologicznej i homiletycznej.

Miejsce wygłoszenia wymienionych kazań wydaje się w świetle informacji zapisanych w edycji oczywiste: ogólnie rzecz nazywając, są to zakonne kościoły Poznania. Ale już konkretyzując ich lokalizację, dzisiejszy czytelnik może nieraz natrafić na trudności. Dwukrotnie o. Szymon głosił kazania w kościele reformatów $(1724,1728)$. Konwent reformacki, podobnie jak wszystkie inne domy zakonne w mieście, został zniesiony przez władze pruskie w pierwszej połowie XIX wieku, a obecnie nie tylko nie jest świątynią zakonną, ale również nie należy do Kościoła rzymskokatolickiego. Stąd w jednym $\mathrm{z}$ tekstów na jego temat, powstałym w nowszych czasach, został nazwany „zapomnianym klasztorem”18. Określenie natomiast innego kazania o św. Franciszku jako wygłoszonego „u franciszkanów” (w 1727 roku) wydaje się niezupełnie jednoznaczne, tzn. można mieć wątpliwość, w którym kościele rzeczywiście zostało wygłoszone. Istniały bowiem w tym czasie trzy konwenty duchowych synów św. Franciszka z Asyżu: bernardynów na placu Bernardyńskim, reformatów na Śródce oraz franciszkanów konwentualnych pod Zamkiem, stąd każda z tych świątyń mogła otrzymać miano „franciszkańskiej”. Ponieważ jednak dosyć konsekwentnie pierwszą z wymienionych wspólnot nazywano bernardynami, a drugą reformatami, można z dużym

${ }^{18}$ Z. Kurzawa, Zapomniany klasztor. Dawny kościót i klasztor Reformatów, „Kronika Miasta Poznania”, 1997, nr 1: Śródka, Ostrówek, Św. Roch, s. 129-152. Zob. też: Kronika Reformatów poznańskich, oprac. J. Wiesiołowski, S.B. Tomczak, G.A. Wiśniewski, Poznań 2006; J. Pawłowczak, Zniesienie i wymarcie zakonu reformatów na Śródce, „Kronika Miasta Poznania”, 10 (1932), nr 1, s. $1-41$. 
prawdopodobieństwem przyjąć, że w tym wypadku chodzi o kościół franciszkanów konwentualnych.

Choć najliczniejszą grupę wśród poznańskich kazań o. Szymona stanowią kazania wygłoszone „u karmelitów”, to jednak nie ma pewności, czy wszystkie zostały wygłoszone w należącym do nich kościele pw. Bożego Ciała ${ }^{19}$. Zakon ten bowiem posiadał w Poznaniu jeszcze drugą, mniejszą i niższej rangi placówkę. Był to dom zakonny w stopniu rezydencji wraz z kaplicą pw. Najświętszej Krwi Pana Jezusa w obrębie murów miejskich. Niekiedy z treści kazania można odnieść wrażenie, że było ono głoszone właśnie w tej karmelitańskiej kaplicy. Nie ma powodów, by taką możliwość wykluczyć. Niemniej w innych przypadkach o. Szymon czerpie wątki treściowe z samego położenia kościoła Bożego Ciała; ponieważ kościół ten zbudowany był na „błoniach miejskich", stąd koncept jednego z kazań opiera się na paralelizmie: łąki miejsce pastwiska, odosobnienie - pustynia wybrania Izraela ${ }^{20}$.

Inna uwaga nasuwa się przy lekturze kazania wygłoszonego w 1730 roku „u klarysek”21. Chodzi tu z całą pewnością o kościół klasztorny bernardynek, gdyż mniszek klarysek w Poznaniu nigdy nie było ${ }^{22}$. Kościół ich nazywany był przynajmniej w nowszych czasach i jest nazywany obecnie kościołem pw. Przemienienia Pańskiego. W rzeczywistości nosił tytuł Najśw. Salwatora, którego figura słynąca łaskami do dziś znajduje się w głównym ołtarzu ${ }^{23}$. Potwierdzenie tego wezwania znajdujemy w kazaniu o. Szymona:

Rozumiem że wszystkim wiadoma, iż pomniejsze luminarze niebieskie, od słońca sobie komunikowaną przyświecają jasnością, toć i ja na dobrym fundamencie sobie perswadować, i wam Bogu poświęcone dziewice ominować mogę, iż mistyczne sprawiedliwości słońce, kordiał serc waszych panieńskich Jezus, cudowny w tym ołtarzu Salwator, jako jutrzenkom jakim rano na chwałę Jego wschodzącym, swego z Nieba udziela światła, poświęcającą poświęca, oświecającą objaśnia was łaską Zbawiciel. Dochodzę figury, czemu figurę Salwatora za pieczęć klasztorną obrałyście sobie święte dziewice, gdyż z herbu poznać, czym się kto rodzi. Cokolwiek bowiem pieczętuje Salwator, już to dziedziczne do nieba prawo; cokolwiek pod pieczęcią wychodzi Zbawiciela, już to prawna do chwały

${ }^{19}$ O klasztorze i kościele karmelitów zob. np.: T.M. Trajdos, U zarania karmelitów w Polsce; T. Ratajczak, Kościół Bożego Ciała w Poznaniu, Poznań 2014. Ze starszych prac zob. np.: J. Łukaszewicz, Krótki opis historyczny kościołów parochialnych, kościótków, kaplic, klasztorów, szkótek parochialnych, szpitali i innych zaktadów dobroczynnych $w$ dawnej dyecezyi poznańskiej, t. I (dalej: Łukaszewicz I), Poznań 1858, s. 159-163.

${ }^{20}$ Por. Dyaryusz, s. 138.

${ }^{21}$ Por. tamże, s. 232-239.

${ }^{22}$ Por. Łukaszewicz I, s. 168-169.

${ }^{23}$ Por. M. Borkowska, Zakony żeńskie w Polsce w epoce nowożytnej, Lublin 2010, s. 311; tam też podstawowe wskazówki archiwalne i bibliograficzne. 
Boskiej sukcesja; księga to żywota, co Niebieski pieczętuje Baranek. Toć widzę pewnieście już sukcesorki do Nieba, gdy i serca i imiona niebieski pieczętuje Salwator ${ }^{24}$.

Jeszcze inną uwagę co do miejsca, nasuwają kazania wygłoszone u karmelitów bosych $(1728,1729)$. W pierwszym z tych kazań ${ }^{25}$, a oba są poświęcone św. Józefowi, karmelita nie wspomina ani słowem o jego obrazie umieszczonym w kościele poznańskim. Natomiast przytacza dość szczegółowy opis obrazu przedstawiającego Zaślubiny Maryi i Józefa, który widział w miejscowości Trąbki; chodzi o Trąbki Wielkie koło Pruszcza Gdańskiego ${ }^{26}$. Skądinąd oba kazania wygłoszone w uroczystość św. Józefa u karmelitów bosych potwierdzają zwyczaj nadawania szczególnej rangi temu obchodowi w poznańskim kościele, który nosił wezwanie św. Józefa ${ }^{27}$. Treść kazania o. Szymona można uznać za pełen rewerencji ukłon w stronę karmelitów bosych. W panegirycznym fragmencie kazania porównuje ich do korony na głowie ich duchowej matki, czyli św. Teresy od Jezusa. Uzasadnia to tym, że „zdziecinniały jak głupie dziecko świat ogniem miłości i żarliwości honoru Boskiego karmili i karmią karmelici" ${ }^{28}$. Interesujące jest w tym samym miejscu nawiązanie do kazania Jana Gersona na święto Narodzenia Najświętszej Maryi Panny, gdzie jest mowa, że jak mąż jest głową kobiety, tak św. Józef głową Najświętszej Maryi Panny ${ }^{29}$, po czym o. Szymon dochodzi do konkluzji typowo barokowej: zatem to święty Józef jest otoczony koroną gwiazd dwunastu, o których mówi Apokalipsa (12,1).

Konkretne okoliczności czasu wygłoszenia wymienionych kazań są okazją do poczynienia szeregu innych uwag. Fakt, że wiążą się z rokiem liturgicznym, jest czymś oczywistym, ale np. w kazaniu na dzień św. Franciszka w 1724 roku $^{30}$ o. Szymon podaje następującą ciekawostkę liturgiczną:

${ }^{24}$ Dyaryusz, s. 238.

${ }^{25}$ Por. tamże, s. 58-62.

${ }^{26}$ Por. tamże, s. 59. Kaznodzieja mówi o obrazie widzianym „15 lat temu” - czyli ok. roku 1714 - roku rozpoczęcia przez niego nowicjatu. Czy była to parafia rodzinna o. Szymona, czy może po prostu w trakcie odbywania nowicjatu miał okazję tam się znaleźć, tego nie wiemy. Wspomniany przez niego pleban wymalowany na tymże obrazie byłby może tożsamy z ks. Bardębasem, o którym w: T. Nowicki, Słownik biograficzny rządców parafii archidiakonatu pomorskiego w XVIII wieku, Lublin 2003, s. 36, 277-278. O parafii w Trąbkach: por. T. Nowicki, Trąbki Wielkie, [w:] EK, t. 19, Lublin 2013, kol. 997-998. Temat zaślubin Józefa i Maryi, dość istotny w dobie baroku, był już przedmiotem studiów, np.: M. Gołębiowski, Malżeństwo Józefa i Maryi w literaturze i piśmiennictwie staropolskim doby potrydenckiej, Kraków 2015.

${ }^{27}$ Por. B.J. Wanat, Kult św. Józefa Oblubieńca Najświętszej Maryi Panny u Karmelitów Bosych w Poznaniu, Poznań 2014, s. 109.

${ }^{28}$ Dyaryusz, s. 64.

${ }^{29}$ Por. tamże, s. 64.

${ }^{30}$ Por. tamże, s. 333-338. 
Chwalę świętą wielkopolskich województw zelozyą. Od roku 1508 dzień Franciszka św. jako powszedni, obchodzić zaczęli Polacy; od lat kilkunastu, wielkopolskie województwa, jako solennie uroczysty. Po dziś dzień po kościelnych na te województwa rubrykach, festum celebrare ad populum, dzień Franciszka św. ${ }^{31}$

Inną specyfiką liturgiczną związaną z miejscem było święto św. Andrzeja Korsyna, patrona Poznania. Choć Dyaryusz nie podaje bliższych okoliczności wygłoszenia dwóch kazań na to święto ${ }^{32}$, to warto zatrzymać się nad zawartym tam porównaniem Poznania do Jerozolimy:

Poznałeś Poznaniu metropolio wielkopolskich województw św. Korsyna łaskawość, nie tylko poznałeś ale i doznałeś, więc za Patrona świętego obrałeś wyznawcę, chwalę szlachetny Poznaniu nabożeństwo twoje, czegoż ci ten dylekt Boski u Boga nie uprosi? Jerozolimy szczęście było, że jej Pan Bóg niebieską straż naznaczył: super muros tuos Jerusalem constitui custodes, tota die \& tota nocte in perpetuum tacebunt; w Jerozolimie dawnej Najśw[iętszy] Jedynak Boski od niezbornego zamordowany żydostwa, w Poznaniu trzy Najśw[iętsze] od niecnotliwej Synagogi kłote nożami hostie, więc drugą Jerozolimą Poznań, masz podobne jak dawna Jerozolima szczęście, oto św. Korsyn czujnego nie mruży oka, nie kurczy dobroczynnej ręki, we dnie i w nocy na pilnej stoi straży super muros tuos \&c. Doznałeś łaskawości św. patrona Poznaniu, gdy się podczas pierwszego powietrza nad ratuszną pokazawszy wieżą, wszelkie powietrzne uśmierzył choroby i bolączki, widziało wielu jako święty strażnik na koniu białym miejskie objeżdżał mury, i dotychczas w tej świątyni łaskami słynie, toć godzien weneracji naszych, godzien nieustających afektów; ma serce Boskie u siebie św. Patron, czegoż nam więcej trzeba? Nakłoni go pewnie na supliki nasze, jeżeli nieustający obaczy afekt ${ }^{33}$.

Andrzej Wojtkowski pisał o św. Andrzeju Korsynie jako zapomnianym patronie Poznania ${ }^{34}$, tym bardziej zatem ciekawi motyw opieki nad miastem opisany przez o. Szymona.

Ten sam motyw porównania Poznania do Jerozolimy powraca w jednym z kazań na obchód „Znalezienia Trzech Hostii”, inny charakterystyczny dla staropolskiego Poznania dzień szczególnej wagi duchowej i religijnej. Czytamy w kazaniu o. Szymona:

31 Tamże, s. 338.

32 Por. tamże, s. 35-41. Jest i drugie kazanie nieokreślone przez wydawcę co do czasu i miejsca wygłoszenia: „Na dzień Św. Andrzeja Korsyna w niedzielę mięsopustną”. Por. tamże, s. 41-46.

33 Tamże, s. 40.

34 Por. A. Wojtkowski, O cudzie trzech hostii i zapomnianym patronie miasta Poznania, „Kronika Miasta Poznania” (1990), nr 3-4, s. 89-105 (przedruk z: „Kronika Miasta Poznania”, 14 (1936), s. 464-489), szczególnie s. 103-104. 
Wszakże i Poznań drugą się nazywać Jerozolimą może, w którym Jedynak Boski, od zawziętego żydostwa, w Najśw[iętszych] zdespektowany Hostiach. Jerozolimskie ulice krwią niewinną, a sklep kamienicy poznańskiej krwią cudowną zafarbowa ${ }^{35}$.

Do tych szczególnych liturgicznych dni świątecznych, podczas których kazania wygłaszał o. Szymon, dodajmy uroczystość Bożego Ciała w kościele tegoż wezwania (a więc u samych karmelitów strictioris observantiae), św. Jacka u dominikanów, św. Franciszka u franciszkanów, św. Klary u klarysek (bernardynek), a także dwie uroczystości szczególnie solennie obchodzone w świątyni jezuitów: św. Ignacego i Najświętszego Imienia Jezus; to ostatnie w dzień Nowego Roku ${ }^{36}$.

Kazania u jezuitów (zarówno w 1725, jak i w 1727 roku) pozwalają zresztą zatrzymać się nad ciekawą, powtarzającą się, refleksją o. Szymona o „upadku” uroczystości Imienia Jezus, mianowicie o małej liczbie wiernych uczestniczących w obchodzie tego święta w jezuickiej świątyni. Kaznodzieja komentuje to następująco:

Czytałem list konfidencjalny od pewnego kapłana do pruskiego ziemianina już w leciech podeszłego pisany: dla słabości zdrowia i wielkiej powietrza alteracji w dzień Nowego Roku na należące nie zajechał nabożeństwo, ledwie po skończonej dewocji, godny pisze do niego Prałat: Et miror \& offendor multum, in renovatione cujuslibet anni, semper te esse annis grandaevum novi, nunc juvenem referes ecce festivum Sanctissimi Nominis Jesu diem in juvenili sepelivisti pulvere! I dziwuję się i gorszę się wielce, każdego Roku poważnego znałem Cię starca, dziś na jakiegoś młodzika czyli malinkę, patrzę dziecinę: dzień święty Najświętszego Imienia Jezus w dziecinnym pogrzebałeś piasku. Jakbym dziś podobne do wszystkich czytał listy, jest się czemu zadziwić, dopieroż nie jednemu pogorszyć; często lada słabostka albo dziecinne zabawy święte grzebią uroczystości. Zmalały albo zdziecinniały przy wielkim Jezusa Imieniu chrześcijańskie dewocje, owym igraszki, innym pieszczone muszczki albo stroje, należące zarzucają nabożeństwo ${ }^{37}$.

Święta roku liturgicznego zawarte w kalendarzu Kościoła powszechnego lub partykularnego nie były jednak jedynymi powodami wygłaszanych kazań. Przynajmniej dwa z nich wiązały się z obecnością funkcjonujących w Pozna-

${ }^{35}$ Dyaryusz, s. 285.

${ }^{36}$ Jezuici u swych początków byli najżywiej związani z pobożnością ku Imieniu Jezus. Stąd ich nazwa oraz herbowy chrystogram IHS. O. Szymon nawiązuje do tego faktu, mówiąc: „Imię Jezus Societas Jesu w słonecznych maluje promieniach jakoby każdemu wiadomo na oko pokazując, że jako słońce w swoim nie ustaje biegu, tak przez Societatis lata, imienia Jezusowego uroczystość swojej nie ma konkluzji u socjuszów Jezusowych". Por. Dyaryusz, s. 6.

${ }^{37}$ Tamże, s. 7. 
niu bractw Opatrzności Bożej i św. Józefa. Bractwo Opatrzności istniejące od 1721 roku, jak wynika z kazań wygłoszonych przez o. Szymona w latach 1727 i $1729^{38}$, miało za swych patronów także apostołów św. Szymona i św. Judę. Z kontekstu wynika, że jego siedzibą był kościół Bożego Ciała. Drugim było bractwo św. Józefa, dla którego nasz karmelita głosił kazanie w kościele karmelitów bosych w 1729 roku $^{39}$.

Ze szczególną okazją związane było kazanie z 1728 roku, opisane jako wygłoszone u reformatów ,przy solennej introdukcji neo-kanonizowanych" 40 . Chodziło tu o typową dla tej epoki uroczystość uczczenia niedawno kanonizowanych świętych, w tym przypadku byli to: Jan z Perugii, Piotr z Sassoferrato $^{41}$, Franciszek Solano ${ }^{42}$ i Jakub z Marchiii ${ }^{43}$. Kazanie nie zawiera jednak żadnych bliższych wiadomości o przebiegu tego obchodu. Natomiast pewien urok posiada zamieszczona $\mathrm{w}$ tym kazaniu captatio benevolentiae:

Stanę ja przy tej Ewangelicznej decyzji, i dowiodę; że: neo-kanonizowani Franciszka św. synowie, przy ludzkiej tylko postaci, prawdziwie Anielską na sobie wyrazili perfekcją. Acz nie perfekt ale lichota dalszy będzie dyskurs, jednakże najdoskonalszej chwały Twojej pragnie. Ens perfectissimum, w Najśw. Sakramencie utajony Boże ${ }^{44}$.

Z kolei w kazaniu z 1729 roku na dzień Nawiedzenia Najświętszej Maryi Panny ${ }^{45}$, które zostało wygłoszone z okazji mszy prymicyjnej, o. Szymon nie wymienia nawet z imienia dominikańskiego prymicjanta.

Podobna sytuacja ma miejsce podczas kazania z 1728 roku, wygłoszonego w dzień św. Michała w świątyni Bożego Ciałą z dość osobliwej, jak na dzisiejsze czasy, okazji: błogosławieństwa nowo wybranych urzędników miejskich. Kaznodzieja nie wymienia jednak ani ich imion, ani powierzonych urzędów, ani jakichkolwiek innych informacji odnoszących się do tego ważnego w życiu miasta wydarzenia ${ }^{46}$, pochwala natomiast samą ideę zwrócenia się do Boga o błogosławieństwo ${ }^{47}$.

${ }^{38}$ Por. tamże, s. 365-374.

${ }^{39}$ Por. tamże, s. 62-67.

${ }^{40}$ Tamże, s. 78- 84.

${ }^{41}$ Por. Acta sanctorum, Augusti, t. VI, Antwerpiae 1743, s. 837-842; Isidoro da Villapadierna, Giacomo da Perugia e Pietro da Sassoferrato, beati, martiri, [w:] Bibliotheca sanctorum, t. VI, Roma 1969, kol. 1052n.

${ }^{42}$ Por. J. Duchniewski, A. Kurek, Franciszek Solano, [w:] EK, t. 5, Lublin 1989, kol. 464.

${ }^{43}$ Por. J. Duchniewski, Jakub z Marchii, [w:] EK, t. 7, Lublin 1997, kol. 705.

${ }^{44}$ Dyaryusz, s. 79.

${ }^{45}$ Por. tamże, s. $163-168$.

${ }^{46}$ Tamże, s. 321-326.

${ }^{47}$ Por. tamże, s. 323. 
Mówiąc o kazaniach o. Szymona, wypada zatrzymać się jeszcze raz przy powracającym w kazaniach głoszonych w kościele Bożego Ciała motywie Trzech Hostii i zwrócić uwagę na jego własne pojęcie o historii tego wydarzenia. W jednym z kazań (z 1729 roku) podaje opis kradzieży hostii, który według niego miał miejsce przed 330 laty, czyli w roku 1399. Dramatyczny opis świętokradztwa i cudownego wylania Krwi podsumowuje następująco: „Zbroczyła krew cudowna stół, ziemię, i mury kamienicznego sklepu, ale twardszych nad diament serc nieludzkich nie zmiękczyła"48. Kazania wygłoszone na „Pamiątkę znalezienia Trzech Hostii” z $1727^{49}$ i 1728 roku $^{50}$ przypominają poznańską, a następnie również karmelitańską tradycję cudu eucharystycznego związanego z założeniem konwentu Bożego Ciała, który król Władysław Jagiełło powierzył karmelitom. Ojciec Szymon zestawia z cudem poznańskim nowsze opowieści zaczerpnięte z dzieła Sebastiana Miczyńskiego Zwierciadło Korony Polskiej z 1618 roku $^{51}$, ale zasadniczo skupia się na dość dokładnym opowiedzeniu jednej z wersji tych wydarzeń.

W końcu krótka uwaga o kazaniu maryjnym z okazji święta Narodzenia Najświętszej Maryi Panny, które to kazanie według informacji w Dyaryuszu miałoby być wygłoszone w kościele pw. Bożego Ciała w Poznaniu w 1731 roku $^{52}$. Wiarygodność tej informacji można by podać w wątpliwość, gdyż nasz kaznodzieja od roku 1730 był podprzeorem w Bydgoszczy, gdzie właśnie w kościele karmelitów święto Narodzenia Maryi było obchodzone ze szczególnym nabożeństwem. Samo kazanie natomiast nie zawiera żadnych elementów, które pozwoliłyby na rozstrzygnięcie kwestii, czy było ono wygłoszone rzeczywiście w Poznaniu, czy może raczej w Bydgoszczy.

\section{Kazania o. Szymona wygłoszone w innych miejscowościach Wielkopolski}

Dziewięć innych kazań o. Szymona zostało wygłoszonych w różnych miejscowościach Wielkopolski, położonych dalej czy bliżej Poznania. W jednym z kazań przekazuje relację pewnego prałata z pobytu w którymś z go-

${ }^{48}$ Tamże, s. 140.

${ }^{49}$ Por. tamże, s. 277-281.

${ }^{50}$ Por. tamże, s. 282-288.

${ }^{51}$ Por. K. Estreicher, Bibliografia Polska, t. XXII, s. 354. Zygmunt III w tym samym roku 1618 zakazał drukowania i rozpowszechniania dzieła, które jednak miało jeszcze inne wydania. Jak widać, cieszyło się poczytnością w całej dobie baroku. Dwa epizody, które przywołuje o. Szymon, są opatrzone datami 1556 i 1752 (druga data jest błędem drukarskim, Zwierciadło podaje ów drugi epizod pod rokiem 1562).

${ }^{52}$ Dyaryusz, s. 288-295. 
ścińców wielkopolskich; mogło się to przytrafić także samemu o. Szymonowi w czasie jego podróżowania do kościołów, w których miał wygłosić kazanie.

Nie dawno w Wielkiej Polszcze, trafia się do gościńca w święto, podróżny, ale zawsze nabożny prałat, wchodzi do izby, na wesołe napada tańce, i przy każdej parze ludzi, dwóch widzi jak w sforze czartów; pojrzy dalej, aż tu za stołem, po oknach, po licach, ledwie nie wszyscy biesowie z piekła, tańcującym i żłopiącym dodając ochoty. Zadziwi się pobożny prałat, i wpół martwym rzecze językiem: rozumiałem żem do gościńca, a jam do piekła zajechał! $!^{53}$

Pod względem chronologii prawie wszystkie z tych kazań pozapoznańskich wygłoszone zostały w czasie pełnienia przez o. Szymona urzędu kaznodziejskiego w klasztorze w Poznaniu (1727-1730), jedno natomiast zostało datowane na 1731 rok. Wykaz tych kazań w porządku czasowym przedstawia się następująco:

1727 Śnieciska - w dzień św. Marcina (strony w Dyaryuszu: 402-406), 1727 Brodnica za Poznaniem - w dzień św. Katarzyny (s. 411-416),

1728 Lubiń, kościół parafialny przy klasztorze benedyktynów w dzień św. Leonarda (s. 396-402),

1728 Brodnica po raz drugi - w dzień św. Katarzyny (s. 416-421),

1729 Starołęka pod Poznaniem - mowa ,przy erekcji kolossu S. Janowi Nepomucenowi miana" (s. 117-119),

1729 Kiszkowo - w uroczystość Świętej Trójcy, przy „,solennej introdukcji” bractwa św. Józefa (s. 131-137),

1729 Żydowo pod Poznaniem - w uroczystość Wniebowzięcia Najświętszej Maryi Panny (s. 239-246),

1729 Lusowo pod Poznaniem - w dzień św. Jadwigi (s. 355-359),

1731 Szamotuły, w kolegiacie - w uroczystość Świętej Trójcy ,z okoliczności cudownego Obrazu Najśw. Maryi Panny” (s. 124-131).

W zdecydowanej większości są to kazania wygłoszone przy okazji uroczystości patronalnych kościołów mających prawa parafialne. Jest zatem oczywiste, że kościoły te noszą wezwania świętych (lub tajemnicy Trójcy Świętej), na których cześć o. Szymon głosił swoje kazania podczas miejscowego odpustu. Nieco inna była okazja działalności kaznodziejskiej o. Szymona w Starołęce, Szamotułach i Żydowie.

Ze szczególnych względów na uwagę zasługuje mowa z 1729 roku wygłoszona w Starołęce ${ }^{54}$, obecnie dzielnicy Poznania, a wówczas majątku nale-

${ }^{53}$ Tamże, s. 382.

${ }^{54}$ Tamże, s. 117-119. 
żącym do poznańskich karmelitów z klasztoru Bożego Ciała. Sam o. Szymon mówi o tym wprost: „A! dobrześ sobie ubogą ubogich Eliasza św[iętego] synów obrała dziedzino, rozumiem że nad złote statuy twój sobie święty Patron szacuje afekt" 55 . Okolicznością bezpośrednią było bowiem ustawienie i poświęcenie figury św. Jana Nepomucena (figury te zwano niekiedy „nepomukami”), dziś już zapewne nieistniejącej i zapomnianej ${ }^{56}$.

Kazania typowo odpustowe wygłosił o. Szymon w Śnieciskach ${ }^{57}$ koło Zaniemyśla ku czci św. Marcina w 1727 roku $^{58}$, w Brodnicy ${ }^{59}$ koło Śremu na dzień św. Katarzyny w $1727^{60}$ i 1728 roku $^{61}$, w Lubiniu ${ }^{62}$ na obchód ku czci św. Leonarda w 1728 roku $^{63}$, w Kiszkowie w uroczystość Świętej Trójcy w 1729 roku, w Żydowie ${ }^{64}$ na Wniebowzięcie NMP w 1729 roku $^{65}$ i w Lusowie $^{66}$ na dzień św. Jadwigi w 1729 roku $^{67}$.

Kazanie drugie z Brodnicy (z 1728 roku), zawierające opis obrazu św. Katarzyny z miejscowego kościoła, jest tym cenniejsze, że prawdopodobnie wraz z kościołem i sam obraz spłonął w XIX wieku ${ }^{68}$. Całe kazanie jest zbudowane jako komentarz do poszczególnych symboli widocznych na obrazie, tak jak pojawiają się one w żywocie św. Katarzyny i jak są komentowane w znanych w epoce zestawieniach typu Mundus symbolicus ${ }^{69}$.

${ }^{55}$ Tamże, s. 117.

${ }^{56}$ Por. M.J. Mika, Kult św. Jana Nepomucena w Poznaniu, „Kronika Miasta Poznania” (1937), s.225-231, przedruk w: „Kronika Miasta Poznania” (1990) nr 3-4, s. 203-207. Nie wspomina się tam jednak o figurze w Starołęce, która była wówczas wsią dosyć odległą od ówczesnego miasta lewobrzeżnego.

${ }^{57}$ Por. Łukaszewicz I, s. 329-330.

${ }^{58}$ Dyaryusz, s. 402-406.

59 Por. np.: J. Łukaszewicz, Krótki opis historyczny kościołów parochialnych, kościótków, kaplic, klasztorów, szkótek parochialnych, szpitali i innych zakładów dobroczynnych $w$ dawnej dyecezyi poznańskiej, t. II (dalej: Łukaszewicz II), Poznań 1858, s. 50-51.

${ }^{60}$ Dyaruysz, s. 411-416.

${ }^{61}$ Tamże, s. 416-421.

${ }^{62}$ Por. Łukaszewicz II, s. 37-40.

${ }^{63}$ Dyaryusz, s. 396-402. Kaznodzieja zaznacza okoliczność wygłoszenia tego kazania następująco: „Przy dorocznej uroczystości św. Leonarda, winszujęć przezacna Parafio cudotwórnego Patrona, ani się lękaj, w rozlicznych świata nieszczęściach, i przypadkach, mocną niezwyciężony Cudotwórca deklaruje obronę, ad quae confugias Ora Leonis habet. Lwem stawa mocnym, w pustyni św. Benedykta wypieszczonym, święty miejsca tutecznego patron, któż sobą trwożyć, albo któż się obawiać będzie?". Zob. tamże, s. 401.

${ }^{64}$ Por. Łukaszewicz I, s. 297.

${ }^{65}$ Dyaryusz, s. 239-246.

${ }^{66}$ Por. np.: Łukaszewicz I, s. 278-280; M. Wrzeszcz, Lusowo, [w:] EK, t. 11, Lublin 2006, kol. 227.

${ }^{67}$ Dyaryusz, s. 355-359.

${ }^{68}$ Por. tamże, s. 417.

${ }^{69}$ Por. F. Picinelli, Mundus Symbolicus, wyd. wł. 1635, wyd. łac. 1681-1687. 
Podczas kazania w Lubiniu pojawia się powracający w kaznodziejstwie o. Szymona motyw ubolewania nad osłabieniem pobożności, w tym przypadku chodzi o kult św. Leonarda: „O! sromotne niemoty! milczymy w nabożeństwach, uważmyż co za czas w tak małym grzebiemy czasie; milczą gorące modlitwy, nabożne prekacje i westchnienia, więc że dobry w pożądanym czasie nużże zginął porządek"70.

Kazanie wygłoszone w Kiszkowie w roku 1729 w uroczystość Trójcy Świętej ${ }^{71}$, poza uczczeniem tej tajemnicy Boskiej, miało w istocie jeszcze jedną ważną przyczynę, bowiem tego dnia dokonywano tam zaprowadzenia bractwa św. Józefa. Nie mamy jednak w związku z tym żadnych dodatkowych uwag kaznodziei.

Kazanie w Lusowie, które o. Szymon wygłosił w roku 1729 na dzień św. Jadwigi, daje nam wiadomość, że w kościele tamtejszym przechowywana była relikwia świętej: „Pomyślcie tu sobie chrześcijanie, podobno przy relikwiach Jadwigi św. którymi się to święte zaszczyca miejsce [...]"72.

Wreszcie ostatnie ze swych wielkopolskich kazań o. Szymon wygłosił w Szamotułach w uroczystość Trójcy Swiętej w 1731 roku $^{73}$. Nasz karmelita był już wówczas podprzeorem w klasztorze bydgoskim ${ }^{74}$. Właśnie w tę ogólnokościelną uroczystość liturgiczną obchodzona była pamiątka przeniesienia w 1666 roku obrazu Matki Bożej do miejscowej świątyni ${ }^{75}$. Rocznica tego przeniesienia obrazu obchodzona była uroczyście także w późniejszych latach, o czym świadczy wydane drukiem wygłoszone w 1762 roku kazanie Jana Kantego Toryaniego pt. Wydatność Tróycy Przenayświętszey w Maryi ${ }^{76}$.

${ }^{70}$ Dyaryusz, s. 397.

${ }^{71}$ Tamże, s. 131-137.

${ }^{72}$ Tamże, s. 358.

${ }^{73}$ Tamże, s. 124-131.

${ }^{74}$ Por. AKK, Decretale provinciae strictioris observantiae, AKKr 168/397, s. 129, 131.

75 Por. K. Jodłowski, Starodruk ,Wielkimi wsławiona cudami” opisujacy dzieje cudownego obrazu Matki Boskiej z Szamotul i laski przy nim wyproszone. Przyczynek do historii kultury religijnej doby baroku w Wielkopolsce, „Ochrona Zabytków” 52/3 (206) (1999), s. 304-311. Zob. też: Łukaszewicz I, s. 298-304.

${ }^{76}$ Por. Wydatność Tróycy Przenayświętszey w Maryi, Kazaniem Przy dorocznym wprowadzeniu do Kollegiaty Szamotulskiey obrazu Matki Nayświętszey wielkiemi taskami słynącego obchodzie $w$ dzień Świętey Troycy w tymże Kościele Kollegiackim pokazana a potym w ręce Jaśnie Wielmożnego Jegomosci Pana Jana z Mycielina Mycielskiego Starosty Osińskiego Pana y Dobrodzieia przez X. M. Jana Kantego Toryaniego, w Przesławney Akademii Krakowskiey Nauk Wyzwolonych y Filozofii Doktora, w Poznańskiey, Szkoty Poetyki, y Języka Francuzkiego Ordynaryinego Professora, Drukarni Akademickiey Prefekta, z powinnym respektem oddana Roku Pańskiego 1762 dnia 6 czerwca. Por. K. Estreicher, Bibliografia polska, t. XXXI, s. 260. 


\title{
Zakończenie
}

Celem niniejszego artykułu było przypomnienie postaci o. Szymona od św. Antoniego i jego działalności kaznodziejskiej na terenie Wielkopolski. Ojciec Szymon, którego nazwiska rodowego nie znamy, należał do zakonu karmelitów zwanych dawniej trzewiczkowymi, a w ramach tego zakonu do nurtu reformy turoneńskiej, której obserwancki styl życia przyjęło także kilkanaście klasztorów na ziemiach polskich i z czasem otrzymały status prowincji. W latach 1727-1730 o. Szymon pełnił urząd kaznodziei w klasztorze pw. Bożego Ciała w Poznaniu. Kilkanaście wygłoszonych wówczas kazań zostało wydanych drukiem w obszerniejszym zbiorze pt. Dyaryusz odświętny roku kaznodzieyskiego, który ukazał się w 1751 roku w Gdańsku. Jako kaznodzieja w klasztorze poznańskim o. Szymon głosił kazania przede wszystkim w swoim kościele klasztornym. Był jednak zapraszany z posługą kaznodziejską do innych kościołów. W Poznaniu były to wyłącznie świątynie należące do innych zakonów (dominikanie, bernardyni, jezuici, karmelici bosi, reformaci, bernardynki i najpewniej franciszkanie konwentualni). Wyjeżdżał też do innych miejscowości wielkopolskich (Śnieciska, Brodnica, Lubiń, Starołęka, Kiszkowo, Żydowo, Lusowo, Szamotuły). Okazją do wygłaszania tam kazań były najczęściej uroczystości odpustowe w świątyniach parafialnych. Opublikowane w Dyaryuszu teksty oprócz treści teologicznych i hagiograficznych zawierają pewną niezbyt wielką liczbę informacji, które można nazwać historycznymi, a które odnoszą się do okoliczności czasu i miejsca wygłoszonych kazań oraz rzadziej do audytorium, wobec którego o. Szymon wykonywał pracę kaznodziejską.

\author{
ON THE GREATER POLAND SERMONS OF FATHER SIMON \\ OF ST. ANTONY, A CALCED CARMELITE. \\ A CONTRIBUTION TO THE HISTORY OF PREACHING \\ IN GREATER POLAND DURING THE SAXON TIMES
}

Summary

Father Simon of St. Antony (Szymon od św. Antoniego), a calced Carmelite and preacher of the first half of the $18^{\text {th }}$ century, was active in Poznań and other places in Greater Poland. A collection of his sermons titled A Diary of Sermons for the Holy Days of the Year (Dyaryusz odświętny roku kaznodziejskiego) was published posthumously by initiative of the monks of the Greater Poland province of the Most Blessed Sacrament. The Poznan monastery of this province was a place of continued ministry 
of preachers appointed by the provincial chapter. Among them was Father Simon, who during his office as preacher, gave sermons in the Carmelite church of Corpus Christi and other monastic churches in Poznań. He was also invited to preach in various parishes of Greater Poland at parish festivals. His sermons contain various interesting historical details pertaining to life in the Saxon period and the places where he ministered.

Słowa kluczowe: kaznodziejstwo; zakony; karmelici trzewiczkowi; życie religijne w XVIII w.; życie religijne w Poznaniu; życie religijne w Wielkopolsce; Szymon od św. Antoniego

Keywords: preaching; religious orders; calced Carmelites; religious life in the $18^{\text {th }}$ century; religious life in Poznań; religious life in Greater Poland; Simon of St. Antony

\section{BIBLIOGRAFIA}

\section{ŹRÓDLA ARCHIWALNE}

Archiwum Karmelitów w Krakowie na Piasku

sygn. AKKr 168/397, Decretale provinciae strictioris observantiae.

\section{ŹRÓDLA DRUKOWANE}

Acta sanctorum, t. VI, Antwerpiae 1743.

Dyaryusz odświętny roku kaznodzieyskiego należyta pilnościa wyrachowany chrześcijańskim pobożnościom z Ambony zalecony albo Kazania roczne na uroczystości świętych Pańskich przez W.X. Szymona od S. Antoniego [...] miane, po śmierci jego zebrane i do druku podane, Gdańsk 1751.

Kroniczka rezydencji Karmelitów Trzewiczkowych w Poznaniu, oprac. J. Wiesiołowski, Poznań 2005.

Kronika Reformatów poznańskich, oprac. J. Wiesiołowski, S.B. Tomczak, G.A. Wiśniowski, Poznań 2006.

Wydatność Tróycy Przenayświętszey w Maryi, Kazaniem Przy dorocznym wprowadzeniu do Kollegiaty Szamotulskiey obrazu Matki Nayświętszey wielkiemi łaskami stynacego obchodzie w dzień Świętey Troycy w tymże Kościele Kollegiackim pokazana a potym w ręce Jaśnie Wielmożnego Jegomosci Pana Jana z Mycielina Mycielskiego Starosty Osińskiego Pana y Dobrodzieia przez X. M. Jana Kantego Toryaniego, w Przesławney Akademii Krakowskiey Nauk Wyzwolonych y Filozofii Doktora, w Poznańskiey, Szkoły Poetyki, y Języka Francuzkiego Ordynaryinego Professora, Drukarni Akademickiey Prefekta, z powinnym respektem oddana Roku Pańskiego 1762 dnia 6 czerwca.

\section{OPRACOWANIA}

Borkowska M., Zakony żeńskie w Polsce w epoce nowożytnej, Lublin 2010. 
Chodynicki I., Wiadomość historyczna o fundacjach klasztorów zakonu karmelitańskiego niegdyś w Polsce i na Litwie, Lwów 1846.

Duchniewski J., Jakub z Marchii, [w:] EK, t. 7, Lublin 1997, kol. 705-706.

Duchniewski J., Kurek A., Franciszek Solano, [w:] EK, t. 5, Lublin 1989, kol. 464.

Estreicher K., Bibliografia polska, t. XIV, XVIII, XXII, XXX, XXXI.

Flaga J. Działalność duszpasterska zakonów franciszkańskich na ziemiach Rzeczypospolitej w trzeciej ćwierci XVIII wieku (w świetle ankiety zakonnej nuncjusza Giuseppe Garampiego z lat 1773-1774), [w:] Zakony franciszkańskie w Polsce, red. J. Kłoczowski, t. 2: Franciszkanie w Polsce XVI-XVIII wieku, cz. 1, Niepokalanów 1998, s. 338-384.

Flaga J., Działalność duszpasterska zakonów w drugiej połowie XVIII w. (1767-1772), Lublin 1986.

Gołębiowski M., Matżeństwo Józefa i Maryi w literaturze i piśmiennictwie staropolskim doby potrydenckiej, Kraków 2015.

Grzanka B., Dziedzictwo Karmelu. 250 lat kościoła Wniebowzięcia Najświętszej Maryi Panny w Kłodawie, Kłodawa 2016.

Isidoro da Villapadierna, Giacomo da Perugia e Pietro da Sassoferrato, beati, martiri, [w:] Bibliotheca sanctorum, t. VI, Roma 1969, kol. 1052n.

Jędrzejowska A., Pelczarowa M., Polskie piśmiennictwo w gdańskich oficynach drukarskich (XVI-XVIII w.), [w:] Szkice z dziejów Pomorza, t. 2: Pomorze nowożytne, red. G. Labuda, S. Hoszowski, Warszawa 1959.

Jodłowski K., Starodruk ,Wielkimi wsławiona cudami” opisujący dzieje cudownego obrazu Matki Boskiej z Szamotut i taski przy nim wyproszone. Przyczynek do historii kultury religijnej doby baroku w Wielkopolsce, „Ochrona Zabytków” 52/3 (206) (1999), s. 304-311.

Karmelitańskie dziedzictwo Bydgoszczy, red. M. Puziak, Bydgoszcz 2017.

Karpiuk W., Biblioteka Marianów w Puszczy Korabiewskiej, „Archiwa, Biblioteki i Muzea Kościelne" t. 69 (1998).

Kloskowski G., Karmelici trzewiczkowi prowincji wielkopolskiej w XVII-XIX wieku, „Archiwa, Biblioteki i Muzea Kościelne” t. 98 (2012).

Kolak W., Katalog Archiwum OO. Karmelitów w Krakowie na Piasku 1398-1945 (1988), Kraków 1997.

Krajewski M., Oborzańskie Sanktuarium Matki Bożej Bolesnej Pani i Królowej Ziemi Dobrzyńskiej, Kraków-Obory-Brodnica 2016.

Krajewski M., Pod szata Karmelu. Kościót i klasztor Karmelitów w Trutowie, Trutowo-Brodnica 2016.

Kurzawa Z., Zapomniany klasztor. Dawny kościót i klasztor Reformatów, „Kronika Miasta Poznania", 65 (1997) nr 1: Śródka, Ostrówek, Św. Roch, s. 129-152.

Łukaszewicz J., Krótki opis historyczny kościołów parochialnych, kościótków, kaplic, klasztorów, szkótek parochialnych, szpitali i innych zakładów dobroczynnych $w$ dawnej dyecezyi poznańskiej, t. I-II, Poznań 1858.

Mańkowski A., Dzieje drukarstwa i piśmiennictwa polskiego w Prusiech Zachodnich ze szczegótowa bibliografia druków polskich zachodniopruskich, „Roczniki Towarzystwa Naukowego w Toruniu" t. 18, 1911.

Mika M.J., Kult św. Jana Nepomucena w Poznaniu, „Kronika Miasta Poznania” (1937), s. 225-231; przedruk: „Kronika Miasta Poznania” 1990, nr 3-4, s. 203-207.

Murawiec W., Idliński Eliasz od św. Franciszka, [w:] SPTK, t. 2, Warszawa 1982, s. 86.

Murawiec W., Jan od św. Władystawa, [w:] SPTK, t. 2, Warszawa 1982, s. 129-130.

Nowak Z., Schreiber Thomas Johannes (1699-1778), [w:] Polski słownik biograficzny, t. 35, Warszawa-Kraków 1994, s. 636-637.

Nowicki T., Stownik biograficzny rządców parafii archidiakonatu pomorskiego w XVIII wieku, Lublin 2003 .

Nowicki T., Trąbki Wielkie, [w:] EK, t. 19, Lublin 2013, kol. 997-998.

Panek B., Karmelici, [w:] EK, t. 8, Lublin 2000, kol. 804-808. 
Pawłowczak J., Zniesienie i wymarcie zakonu reformatów na Śródce, „Kronika Miasta Poznania”, 10 (1932), nr 1, s. 1-41.

Pelczarowa M., Z dziejów oficyn drukarskich w Gdańsku (w. XVI-XVIII), „Rocznik Gdański” 14 (1955), s. 145-165.

Pelczarowa M., Z dziejów oficyn drukarskich w Gdańsku (XVI-XVII w.), Gdańsk 1995.

Picinelli F., Mundus Symbolicus, wyd. wł. 1635, wyd. łac. 1681-1687.

Puziak M., Szymon od św. Antoniego - karmelitański kaznodzieja w Bydgoszczy i okolicy w czasach saskich, „Materiały do Dziejów Kultury i Sztuki Bydgoszczy i Regionu” 19 (2018), s. 23-42.

Puziak M., Uwagi o prowincjałach karmelitańskiej Wielkopolskiej Prowincji Najświętszego Sakramentu w XVIII wieku, ,Studia Bydgoskie” 11 (2017).

Ratajczak T., Kościól Bożego Ciała w Poznaniu, Poznań 2014.

Szudrowicz A., Karmelici w Kcyni (1612-1835). Rola zakonu w życiu miasta i okolicy, Bydgoszcz 2001.

Trajdos T.M., U zarania karmelitów w Polsce, Warszawa 1993.

[Trzysta] 300 lat karmelitów w Trutowie, red. J. Dębiński, Trutowo 2017.

Wanat B.J., Kult św. Józefa Oblubieńca Najświętszej Maryi Panny u Karmelitów Bosych w Poznaniu, Poznań 2014.

Wojtkowski A., O cudzie trzech hostii i zapomnianym patronie miasta Poznania, „Kronika Miasta Poznania”, 14 (1936), s. 464-489; przedruk: „Kronika Miasta Poznania” 1990, nr 3-4, s. 89-105 .

Wrzeszcz M., Lusowo, [w:] EK, t. 11, Lublin 2006, kol. 227. 